\title{
Integrality of care: challenges for the nurse practice
}

\author{
Cuidado integral: desafio na atuação do enfermeiro \\ Cuidado integral: desafío de la actuación del enfermero
}

\section{Solange Meira de Sousa', Elizabeth Bernardino', Karla Crozeta', Aida Maris Peres', Maria Ribeiro Lacerda' \\ ' Universidade Federal do Paraná, Postgraduate Program in Nursing. Curitiba, Paraná, Brazil.}

How to cite this article:

Sousa SM, Bernardino E, Crozeta K, Peres AM, Lacerda MR. Integrality of care: challenges for the nurse practice. Rev Bras Enferm [Internet]. 2017;70(3):504-10. DOI: http://dx.doi.org/10.1590/0034-7167-2016-0380

Submission: 06-10-2016 Approval: 11-13-2016

\begin{abstract}
Objective: to understand the role of the nurse in the collegiate management model of a teaching hospital, in the integrality of care perspective. Method: a single case study with multiple units of analysis, with the theoretical proposition "integrality of care is a result of the care offered to the user by multiple professionals, including the nurse". Data were obtained in a functional unit of a teaching hospital through interviews with 13 nurses in a non-participant observation and document analysis. Results: from the analytical categories emerged subcategories that allowed understanding that the nurse promotes integrality of care through nursing management, team work and integration of services. Final considerations: the theoretical proposition was confirmed and it was verified that the nursing management focus on attending to health care needs and is a strategy to provide integrality of care.
\end{abstract}

ABSTRACT

Descriptors: Health Systems; Comprehensive Health Care; Nursing; Hospitals, Teaching; Hospital Administration.

\section{RESUMO}

Objetivo: apreender a atuação do enfermeiro no modelo de gestão colegiada de um hospital de ensino na perspectiva do cuidado integral. Método: estudo de caso único de múltiplas unidades de análise, com a proposição teórica "o cuidado integral resulta dos vários cuidados oferecidos ao usuário pelos vários profissionais, dentre esses o enfermeiro". Os dados foram obtidos em uma unidade funcional de um hospital de ensino por meio de entrevistas com 13 enfermeiros, observação não participante e análise de documentos. Resultados: a partir das categorias analíticas, emergiram subcategorias que possibilitaram apreender que o enfermeiro promove o cuidado integral por meio do gerenciamento de enfermagem, do trabalho em equipe e da integração entre os serviços. Considerações finais: ratificou-se a proposição teórica e constatou-se que o gerenciamento de enfermagem volta-se para o atendimento das necessidades de saúde e é uma estratégia para o cuidado integral.

Descritores: Sistemas de Saúde; Assistência Integral à Saúde; Enfermagem; Hospitais de Ensino, Gestão Hospitalar.

\section{RESUMEN}

Objetivo: discurrir sobre la actuación del enfermero en el modelo de gestión colegiada de un hospital-escuela, bajo la perspectiva de la atención integral. Método: estudio de caso único de múltiples unidades de análisis con la proposición teórica "el cuidado integral es el resultante de diversos cuidados que varios profesionales, entre ellos el enfermero, ofrecen al usuario". Mediante entrevista a 13 enfermeros, observación no participante y análisis de documentos, se obtuvieron los datos necesarios en una unidad funcional de un hospital-escuela. Resultados: a partir de las categorías analíticas, emergieron subcategorías que consideran al enfermero como un promotor del cuidado integral por medio del gerenciamiento de la enfermería, del trabajo en equipo y de la integración entre los servicios. Consideraciones finales: se ratificó la proposición teórica y se constató que el gerenciamiento de enfermería está volcado a la atención de las necesidades de la salud y es una estrategia para el cuidado integral.

Descriptores: Sistemas de Salud; Asistencia Integral a la Salud; Enfermería; Hospitales-Escuela, Gestión Hospitalaria. 


\section{INTRODUCTION}

Brazil's Constitution of 1988 presented new outlines for the health system, establishing that the individual's health needs ${ }^{(1)}$ must be attended through integrality of care operating in a local and hierarchical network with integrated services and technologies ${ }^{(2)}$. The health care model advocated by the Unified Health System (SUS) suggests that the responsibility for the integrality of care is responsibility of health service providers in the different levels of care, including teaching hospitals, that have reconfigured their management models ${ }^{(3)}$.

Thus, one of the ways to reconstruct hospital management consists of implementing models that stimulate professional autonomy, evidencing the health care coordination and facilitate communication between professionals and different services. This aims to attain a more effective organization, in order to provide Integrality of Care to the users. The Collegiate Management Model, adopted by a teaching hospital in the southern region of Brazil since 2002, represents one of these new management models, with services organized in 23 Functional Units (FU), classified as administrative and care units. The latter include services grouped by similar specialties, following a logic based on "lines of care"(4) that presuppose safe flows of care to attend to health needs $s^{(5)}$ and integrality of patient-centered care.

According to this model, the objective of this line of care is to provide integrality of care, interconnecting the services and impacting the work processes of the health professionals. Each FU has particularities determined by its area; however, all are matrix, meaning they follow the same organizational structure. Therefore, for this research, one of these FUs was chosen, since all follow the same pattern of operation.

The management model of the hospital under study includes the positions of Administrative Supervisor, Medical Supervisor, Nursing Supervisor and Manager. In this functional structure, the Nurse performs his functions in several services as Nursing Professional, Head Nurse and Nursing Supervisor; and may also hold external positions such as Administrative Supervisor and FU Manager. All these professionals takes part in monthly collegiate meetings to make decisions concerning the FU, among them the definition of the positions mentioned ${ }^{(6)}$.

The Nursing Supervisor is responsible for nursing care in all the FU services, which, in turn, have Chief Nurses and Nurses. In this arrangement, nurses coordinate care and, therefore, it is their responsibility to provide quality care ${ }^{(7-9)}$ and promote interaction of different professionals ${ }^{(8)}$. To do so, nurses use a management model that directs nursing care, allows interdisciplinary relationships and provides support to the supervisors, administrators and other staff ${ }^{(10)}$, contributing to the effectiveness of the managerial model.

In the present research, Integrality of care is understood through two aspects ${ }^{(11)}$ : a) regarding the individual in diverse life situations in need of multiple care; b) connected to a health system in which the care must be transversal, that is, provided in a network. Considering these aspects, this study is based on the concept of Integrality of care, both as a SUS guideline and as guidance to provide Integrality of care. Therefore, discussing about Integrality of care, which involves a debate about the practice of the care model proposed by SUS.

Considering that, in the hospital under study, a management model based on lines of care was instituted 13 years ago with the purpose of providing Integrality of Care, and that model observes the public health care policies, we ask: how is the performance of the nurse in the collegiate management model of a teaching hospital from the perspective Integrality of Care?

Therefore, the research aimed at comprehending the nurse's role in the collegiate management model of a teaching hospital from the perspective Integrality of Care.

\section{METHOD}

\section{Ethical aspects}

Initially, contact with the research participants was established. In this opportunity, the objectives of the research were explained, as well as the techniques that would be used for data collection and ethical implications. Subsequently, the interview was scheduled and the days for the non-participant observation were set. The days for the verification of the documents were also defined, according to the availability of each participant. The data collection took place after the explanation of the Informed Consent Form by the researcher and the signing of this document by the research participant.

To present the results, data were codified, identifying the participants with the prefix "Nur", followed by a random letter of the alphabet (Nur A, Nur C ..., Nur M); data regarding the interview, the observation and the documents are identified by the letters "I", "O" and "D", respectively. The research project was approved by the Human Research Ethics Committee of the Federal University of Paraná (UFPR).

\section{Theoretical Methodological framework and study type}

This study used Integrality of Care as theoretical framework, based on two approaches: one related to the multiple care the individual is submitted to, necessary to attend to their needs; the other related to Integrality of Care as the main objective of the health system, provided through the multiple devices in the network. The study is also based on the concept of Integrality of care, as a SUS guideline and as guidance to provide Integrality of Care.

Regarding the methodological framework, this is an integrated single Case Study with multiple units of analysis ${ }^{(12)}$. As part of this framework, a theoretical proposition should be established as guide for the analysis ${ }^{(12)}$, for which the following was defined: integrality of care is a result of the care offered to the user by multiple professionals, including the nurse. This statement was an analytical strategy to understand nurses' performance and how Integrality of Care is performed in the selected FU.

Also in this context, three analytical categories were previously defined, guiding the analysis along with the objective of the study: Integrality of care under the nurses' understanding; nursing management focused on Integrality of Care; and integration of services as potential for assistance integrality. The subcategories that emerged/ from the first category were: care provided by Nursing; and care provided by professionals from the multidisciplinary 
team. The subcategories that emerged from the second category were: nursing management aimed at problem solving; use of management tools; and difficulties related to the nursing management. Finally, from the third category emerged the subcategories: integration determined by flow; and lack of integration causing many different interpretations in the line of care.

The choice for Case Study as methodological framework favored the accomplishment of the objective of this study and along with the theoretical framework allowed in depth understanding of individual, organizational and political aspects expressed in the context of this investigation ${ }^{(12)}$.

This is an exploratory study with qualitative approach. This choice was aimed at understanding the study object through a subjective interpretation and at outlining aspects not recognized in the literature ${ }^{(12-13)}$.

\section{Study scenario}

The research was conducted from February to May 2014 in a FU of teaching hospital. The scenario was limited by the services provided in this FU that count with nurses in their staff, which correspond to the units of analysis of this case study.

The FUs are the form of organization of the management model adopted by the teaching hospital under study. Each FU gathers services to attend to health needs related to specific areas. Regarding the place where this study was carried out, the service provided to the users refers to the cardiovascular and pulmonology area.

\section{Data source}

The population of this study was the 13 nurses assigned to the FU. For the selection of participants, the following inclusion criterion was adopted: being a nurse in the selected FU, regardless of position. The exclusion criterion adopted was any absence during the period of data collection. The sample was non-probabilistic, that is, the choice of participants was intentional; Thus, the sample was closed by exhaustion since all eligible participants participated in the study.

\section{Data collection and organization}

Data collection occurred in the participants' work place, according to the availability of each participant, through a semi-structured interview, non-participant observation and document analysis ${ }^{(12)}$. The interviews were audio-recorded, with a maximum duration of 1 hour and 20 minutes and a minimum duration of 11 minutes and 10 seconds, and included questions related to the previously defined analytical categories, covering aspects related to integrality of care, nursing management and services integration: How do you understand integrality of care? How is the integration of your service with other services in the management unit? How does the nursing integration with other professionals take place? How do you organize the nursing care in your unit? How is the development of strategies to provide integrality of care in your unit? What are the strategies used in your service to attain continuity of care? How does management in your unit promote integrality of care? How does attending to the needs of users facilitate/hinder the work process?
The script of the interview was adapted for the non-participant observation and document analysis, aiming to comprehend the same aspects mentioned, using a field journal to record the information and impressions later organized for the analysis. A total of 103 hours of observation occurred, distributed in the 12-hour day and night shifts, according to the nurses work schedule, when daily clinical situations and management situations were recorded ${ }^{(12)}$. The duration of the observation considered the relevance and repetition of the situations, ending with the saturation of the data after the identification of convergences between the evidences obtained in the interviews. Therefore, some shifts were fully observed while others were not. Through document analysis the monthly scales and standard operating procedures (SOPs) were verified.

\section{Data analysis}

For the data analysis, the theoretical framework and the analytical categories were adopted. The information was transcribed and organized into matrices, favoring data analysis ${ }^{(12)}$. The matrices were specific for each unit of analysis and were constituted according to the analytical categories and to the data collection technique used. This way, tables were constructed arranging the categories in a row and the techniques of data collection in a column, allowing the information crossing and the identification of subcategories. From these matrices, only one matrix was created, in which the data were regrouped, extracting relevant fragments with compacted information. After this process, the final result was expressed by category and subcategories and by examples from each data collection technique used.

\section{RESULTS}

The final sample corresponded to the total number of nurses from the FU under study: 13 participants. These were mostly women $(84.6 \%)$ with mean age of 46.6 years, mean of 6.2 years in service and mean of 16.5 years of professional training. Regarding the functions performed, 07 (54\%) were responsible for care, and 06 (46\%), for management.

From the analytical categories proposed emerged subcategories that allowed the comprehension of the nurses' performance in the perspective of Integrality of Care, through nursing management and occasional actions with the nursing team and multidisciplinary team in the multiple services in the FU.

Category 1: Integrality of Care under the nurses' understanding

The nurses in this study understand Integrality of Care from two perspectives, which resulted in the subcategories "care provided by Nursing" and "care provided by the professionals from the multidisciplinary team".

Regarding the subcategory "care provided by Nursing", the nurse's ability to identify health needs and provide integration leading to teamwork was highlighted, emphasizing communication and articulation. The following data express these understandings:

It's when you take on the whole patient; it's what you do in the post-op of cardiac surgery. You see [the patient] as a whole. For example, there is an employee [...] only for that 
patient, to provide medication, hygiene care, dressing, everything, so that you can attend to all his needs. (I- Nur M)

The team reports to the nurse for information about the patient. (O)

The nurse distributes the patients equally among the employees, who take on the integrality of care $(\mathrm{O})$

Regarding the subcategory "care provided by the professionals from the multidisciplinary team", the need to understand the professional limits is highlighted, as suggested by the following data:

I understand the need this person has for care from other professionals. (Nur K)

The care I can provide no one else can. The care that I perform I can't hand over to another professional, and other professionals rely on me, on my care, on the actions that are prescribed by the nurse. (I- Nur J)

The multi-professional integration is another conditioning factor for integrality of care, emphasizing the nurse's role as articulator of the team, according to the following data:

We deal more with the medical part. (I-Nur C)

Nurse and doctor talk about a patient. (O)

Today, we can talk to Nutrition, explain that the patient can be fed orally, that the nasogastric tube can be removed. (I- Nur J)

Nutritionist talks to the nurse and questions about the possibility of evaluating a patient. $(\mathrm{O})$

\section{Category 2: Nursing management focused on Integrality} of Care

From this category emerged three subcategories regarding the nursing management process in the FU under study.

For the first subcategory, management is focused on solving problems, in order to attend to health needs, with emphasis on the general training of nurses and on the role they play in coordinating care:

Because my work process will attend to the needs of this patient. (I- Nur J)

If we admit a patient who has a heart disease, but he has a neuropathy, we will know how to take care of it [...] because we have a general education. (I- Nur K)

Nurse performs more complex procedures, such as venous ulcer dressing. (O)

The second subcategory highlights the use of management tools to organize the work process, such as leadership, supervision and referral (the nurse) to the nursing team:

[...] If it is not attended by the nurse, if the nurse does not guide the nursing team on how to do it, this care can be neglected, can be incomplete, it does not reach the proposed goal. (I- Nur J)

Nurse tells the blood bank to cancel the blood request. (O)

Today, we reached a point where the team walks alone, but it needs a reference, and this reference is always the nurse. (I- Nur B)

However, the third subcategory points out structural or functional difficulties that limit the management process leading to Integrality of care, with emphasis on inadequate organizational structure; the dichotomy between management and care; and communication failures. The following data point to these aspects:

In my service, the assistance is not organized to provide integrality of care. (I- Nur C)

It's complicated, because we can't take on the whole patient, we don't have the conditions to do that. You are alone on the floor [...] because of a shortage of employees. (I- Nur F)

\section{Category 3: The integration of services as potential for the performance of Integrality of Care}

Two subcategories emerged from the category integration of services.

The first one is related to the integration determined by the flow, which presumes a continued assistance provided by the services.

For our patient to arrive here, he must have been through an ambulatory [...] through a PA, if it is an emergency. So we are in contact with all the hospital units. (I- Nur B)

Patient is admitted to the unit to perform a procedure. The Nursing team receives the patient from an employee of another service. Patient receives orientation. (O)

General SOP 002: Patient transfer. It consists on the procedures to be performed when a patient is transferred from one unit to another, emphasizing the functions of each one. (D)

On the other hand, the second subcategory refers to the lack of integration that causes different interpretations in the line of care, highlighting as the main aspects the lack of integration - not assumed as a negative aspect — and the lack of communication between services:

I don't believe that this lack of integration results in worse care or a deficit in care [...]. I believe that this has no meaning for the care of the patient. (I- Nur K)

We have a better contact with our FU [...] Now, when a patient is admitted to the medical clinic, neurology, they don't always come to us ... we can't always reach them. (I- Nur C)

\section{DISCUSSION}

The health needs, in the context investigated, are identified and attended by multiple health professionals most often 
through integrality of care ${ }^{(14-15)}$. In this context, quality and quantity in the functional work are necessary ${ }^{(15)}$ to deal with the multiple health problems.

The nurse acts as an articulator regarding information concerning users and those related to service standards ${ }^{(16)}$, appearing in this and in several scenarios shown by the literature as the professional who articulates, coordinates and conducts care $^{(7-9,17)}$. This includes identifying needs and demonstrating problem solving skills.

The structure of the health network, still focused on procedures and with too much appreciation of the medical knowledge, puts into question the way integrality of care has been occurring in the devices of the health system ${ }^{(18)}$. This fact is represented in this research by the close relationship with the medical staff in the daily work of the nurses; however, it should also be emphasized that the multiple functions and characteristics attributed to nurses enables them to provide integrality of care, since this same relation with the medical team has two connotations: on the one hand, the valorization of the biomedical model; and, on the other hand, teamwork.

However, it is important to mention that the practices learned in the process of producing care must go beyond technical knowledge; it is also necessary to contemplate the political and organizational fields. In this regard, restoring aspects such as reception, bonding, accountability and solvability is necessary to consolidate Integrality of care, since nursing cannot practice the unarticulated care from other practices and from the organizational context of the SUS, regardless of the level of technological density ${ }^{(18)}$.

Health practices, and more specifically nursing practices, should be analyzed in all their associations with the SUS network. In this regard, the way they are practiced must be aimed at meeting the health needs of individuals. As part of this context, the management practice of nurses is integrated with coordination, supervision and evaluation actions, produced in the orientation, dialogue and negotiation processes between staff, users and families ${ }^{(18)}$.

With this in regard, the coordination necessary for the care and intrinsic to the nursing management is vital ${ }^{(19)}$. The generalist training of the nurse is adjuvant in this care/management process, since it allows the nurse to understand and intervene in health problems and situations more easily ${ }^{(20)}$.

Correlated to this, some tools are crucial to the nursing management; among them, leadership ${ }^{(4,21-22)}$ is essential to coordinate the work of the nursing team and the multidisciplinary team ${ }^{(21-22)}$, since it favors delegation of activities and planning the care. Associated with it, supervision is also central for the care management ${ }^{(22)}$.

However, it is important to point out that in the process leading to difficulties in the management for Integrality of care it's possible to perceive the contradiction between the demands of the institution - often bureaucratic actions - and what is really necessary to the professional practice ${ }^{(19)}$. Thus, an impairment of the nurses' work process becomes evident, making it harder to strengthen the management model adopted in the institution.

Although nursing care is indispensable in this context of study, multi-professional practice represents a new way of organizing work in health, occurring with the necessary articulation mediated by nurses in the use of their management and care functions. Each professional committed to the health of the user contributes to the interdisciplinary care, since the individual is seen from several perspectives ${ }^{(14)}$, showing one of the meanings of Integrality of care expressed in the present study.

The specialty of each professional in face of the complexity of the health problems must be highlighted, since it is crucial to promote health, care, and prevention. In this study, it became evident that Integrality of care was provided at several times by the nursing team and by the professionals of the multidisciplinary team, favoring integrality.

In this regard, Integrality of care may change the way nursing care has been regularly carried out - fragmented, focused on specific issues and centered in the professional. In order to do that, the nurse must assimilate the integrality of care as part of their practice but also inherent to all health professions and, above all, as aligned with integrality ${ }^{(18)}$.

Another important aspect to point out is the integration of services, which demonstrates that achieving a networked care is a condition for integrality of care ${ }^{(23-24)}$. Just as a professional is not able to attend to all the demands of an individual, an isolated service is also not, which explains the logic of internal organization of the FU's services. The FUs have a functional structure aimed at constant integration, since they provide services for a homogeneous public with varied needs, usually according to severity. This way, the defined flows of care contribute to a proper referral of users among the services.

In some moments this integration presented difficulties, recurring on the problem of lack of communication between the services; this aspect hampers the consolidation of the integrality and the recognition of the principles of the collegiate management model of the institution ${ }^{(5)}$.

In view of the model of assistance advocated by the SUS, policies for dealing with diseases must seek not only to reduce occurrences, but also to increase access and guarantee integrality of care. This implies comprehensive actions by Nursing in health care $^{(25)}$.

In this regard, it is valid that nurses develop strategies to integrate the network and provide continuity in health care, with potential to overcome the disarticulation between the levels of primary and hospital care ${ }^{(26)}$. Therefore, the organizational difficulties pointed out in this research demand a different posture from the nurse, since the nursing management may contribute to attend to the health care needs and, by analogy, to provide Integrality of care. In addition, the aspects related to management focused on Integrality of care are favorable, as shown in this research, and capable to strengthen the networked care.

Each professional is responsible for the path of the user in the network, based on the assumption that all of them are aware of the local reality in order to provide orientation regarding the services available ${ }^{(1)}$. Therefore, Integrality of Care is the final product of the relations established between the multiple professionals and the plans of care offered to the user.

In general, the challenge in the nurses' ${ }^{\prime}$ work lies in considering political and organizational aspects related to the SUS network 
and present in the management models of each institution and in improving comprehension regarding Integrality of care, considering this challenge is within a care model that considers meeting the health needs of individuals as basis and guiding axis.

Therefore, for the achievement of Integrality of care it is not necessary to "reinvent the wheel", by redefining formats and restructuring management models or even the current care model. Integrality of care requires, among other things, that nursing actions are integrated with those of other professions. In addition, it is favorable to raise awareness among the professionals regarding the management model of the institution and the contextualization with the management role of the nurses, provided that, at the same time, the nurse assumes its role in the service and in the institution.

\section{Study limitations}

The present research presents limitations related to the multiprofessional practice. Limitations related to communication failures should be highlighted, since communication is a key ingredient of teamwork. Some weaknesses found in the process of integration between the services allows questioning if the management model does indeed favors Integrality of care or if the professionals and/or services did not adhere to the model proposal.

Contributions to the area of nursing, health or public policies

As contribution of this research to the nursing practice we highlight the nursing management as a strategy to provide
Integrality of care. The strategy is aimed at attending to health needs with the actions of the nursing and multidisciplinary teams, guided by the organization of the management model under study. And so, for public health, there are visible subsidies to carry out the so desired integrality of care in the current health system.

\section{FINAL CONSIDERATIONS}

The initial statement of the study was confirmed, meaning that Integrality of care is the final product of the multiple care offered by the nursing team and the multidisciplinary team, as well as of the relations established among the members of these teams; it was also possible to understand that nursing management is one of the tools for providing Integrality of care.

We also emphasize the nurses effort in the clinical care practice, based on the characteristics of their training, which might give them visibility and influence, making them potential promoters of Integrality of care.

Above all, it is important to highlight that Integrality of care is extended beyond nursing care, which is only one aspect among the innumerable health needs of an individual. As a conclusion, the coordination of care is an important feature of the nursing management, which, although specific to a profession, favors reaching integrality of care in all other aspects, since the nursing work, due to a longer time spent in the health services, allows the necessary articulation to provide Integrality of care.

\section{REFERENCES}

1. Bonfada D, Cavalcante JRLP, Araujo DP, Guimarães J. A integralidade da atenção à saúde como eixo da organização tecnológica nos serviços. Ciênc Saúde Colet [Internet]. 2012 [cited 2016 May 13];17(2): 555-60. Available from: http://www.scielo.br/pdf/csc/ v17n2/a28v17n2.pdf

2. Paim JS, Travassos C, Almeida C, Bahia L, Macinko J. The brazilian health system: history, advances, and challenges. Lancet [Internet]. 2011[cited 2016 Mar 02];377(9779):1778-97. Available from: http://www.thelancet.com/pdfs/journals/lancet/ PIIS0140-6736(11)60054-8.pdf

3. Lampert JB, Barbosa Neto F, Streit DS, Moraes VA, Brenelli SL. Hospitais de ensino: a trama da crise. Rev Bras Educ Méd [Internet]. 2013 [cited 2016 Oct 06];37(2):155-6. Available from: http://www.scielo.br/pdf/rbem/v37n2/01.pdf

4. Lelli LB, Bernardino E, Peres AM, Fabriz LA. Estratégias gerenciais para o desenvolvimento de competências em enfermagem em hospital de ensino. Cogitare Enferm [Internet]. 2012 [cited 2016 May 11];17(2):262-9. Available from: http://revistas.ufpr.br/ cogitare/article/view/24932/18480

5. Malta DC, Merhy EE. O percurso da linha do cuidado sob a perspectiva das doenças crônicas não transmissíveis. Interface [Internet]. 2010 [cited 2016 Oct 07];14(34):593-606. Available from: http://www.scielo.br/pdf/icse/v14n34/aop0510.pdf

6. Sousa SM, Aued GK, Bernardino E, Guimaraes MP. Atuação dos enfermeiros em um modelo gerencial de unidades funcionais. In: Vale EG, Peruzzo SA, Felli VEA. (org). Programa de Atualização em Enfermagem. Gestão: ciclo 4. Porto Alegre: Artmed; 2015. p.77-104.

7. Carter JA, Carr LS, Collins J, Petrongolo JD, Hall K, Murray J, et al. STAAR: improving the reliability of care coordination and reducing hospital readmissions in an academic medical centre. BMJ Innov [Internet]. 2015[cited 2016 Oct 02];1(3):75-80. Available from: https://www.ncbi.nlm.nih.gov/pmc/articles/PMC4515994/pdf/bmjinnov-2015-000048.pdf

8. Procter S, Brooks F, Wilson P, Crouchman C, Kendall S. A case study of asthma care in school age children using nurse-coordinated multidisciplinary collaborative practices. J Multidiscip Healthc [Internet]. 2015 [cited 2016 Oct 02];8:181-8. Available from: https://www.ncbi.nlm.nih.gov/pmc/articles/PMC4399592/.

9. Crouch R, McHale M, Palfrey R, Curtis K. The trauma nurse coordinator in England: a survey of demographics, roles and resources. Int Emerg Nurs [Internet]. 2015 [cited 2016 Oct 02];23:8-12. Available from: http://www.internationalemergencynursing.com/ article/S1755-599X(14)00048-2/pdf 
10. Van Bogaert P, Peremans L, de Wit M, Van Heusden D, Franck E, Timmermans O, et al. Nurse managers' perceptions and experiences regarding staff nurse empowerment: a qualitative study. Front Psychol [Internet]. 2015 [cited 2016 Oct 02];6:1585. Available from: https://www.ncbi.nlm.nih.gov/pmc/articles/PMC4604254/pdf/fpsyg-06-01585.pdf

11. Cecílio LCO, Merhy E. Integralidade do cuidado como eixo da gestão hospitalar. In: Pinheiro R, Mattos RA. Construção da integralidade: cotidiano, saberes e práticas em saúde. Rio de Janeiro: IMS ABRASCO; 2003.p. 197-210.

12. Yin RK. Estudo de caso: planejamento e métodos. $4^{\text {a }}$ ed. Porto Alegre: Bookman, 2015.

13. Polit DF, Beck CT. Fundamentos de pesquisa em enfermagem: Avaliação de evidências para a prática da enfermagem. $7^{\mathrm{a}}$ ed. Porto Alegre: Artes médicas, 2011.

14. Queiróz ES, Penna CMM. Conceitos e práticas de integralidade no município de Catas Altas-MG. REME Rev Min Enferm [Internet]. 2011 [cited 2016 Jun 09];15(1):62-9. Available from: http://www.revenf.bvs.br/pdf/reme/v15n1/v15n1a09.pdf

15. Silva FRF, Costa ALRC, Araujo LFS, Bellato R. Prática de enfermagem na condição crônica decorrente de hanseníase. Texto Contexto Enferm [Internet]. 2009 [cited 2016 May 06];18(2):290-7. Available from: http://www.scielo.br/pdf/tce/v18n2/12.pdf

16. Cecílio LC. A morte de Ivan Ilitch, de Leon Tolstói: elementos para se pensar as múltiplas dimensões da gestão do cuidado. Interface [Internet]. 2009 [cited 2016 May 06];13(suppl. 1):545-55. Available from: http://www.scielo.br/pdf/icse/v13s1/a07v13s1.pdf

17. Ferreira-Umpierrez A, Fort-Fort Z. Experiences of family members of patients with colostomies and expectations about professional intervention. Rev Latino-Am Enfermagem [Internet]. 2014 [cited 2016 Mar 03];22(2):241-7. Available from: http://www.scielo.br/ pdf/rlae/v22n2/0104-1169-rlae-22-02-00241.pdf

18. Assis MMA, Nascimento MAA, Pereira MJB, Cerqueira EM. Comprehensive health care: dilemmas and challenges in nursing. Rev Bras Enferm [Internet]. 2015 [cited 2016 Jun 03];68(2):333-8. Available from: http://www.scielo.br/pdf/reben/v68n2/en_0034-7167-reben-68-02-0333. pdf

19. Montezelli JH, Peres AM, Bernardino E. Demandas institucionais e de cuidado no gerenciamento de enfermeiros em um pronto socorro. Rev Bras Enferm [Internet]. 2011 [cited 2016 Jun 03];64(2):348-53. Available from: http://www.scielo.br/pdf/reben/ v64n2/a20v64n2.pdf

20. Canever BP, Prado ML, Backes VMS, Gomes DC. Production of knowledge about the training of nurses in Latin America. Rev Gaúcha Enferm [Internet]. 2012 [cited 2016 Oct 07];33(4):211-20. Available from: http://www.scielo.br/pdf/rgenf/v33n4/en_26. pdf

21. Almeida ML, Segui MLH, Maftum MA, Labronici LM, Peres AM. Instrumentos gerenciais utilizados na tomada de decisão do enfermeiro no contexto hospitalar. Texto Contexto Enferm [Internet]. 2011 [cited 2016 Jun 04];20(esp):131-7. Available from: http://www.scielo.br/pdf/tce/v20nspe/v20nspea17.pdf

22. Santos JLG, Lima MADS. Gerenciamento do cuidado: ações dos enfermeiros em um serviço hospitalar de emergência. Rev Gaúcha Enferm [Internet]. 2011 [cited 2016 Jun 04];32(4):695-702. Available from: http://www.scielo.br/pdf/rgenf/v32n4/v32n4a09.pdf

23. Arce VAR, Sousa MF. Integralidade do cuidado: representações sociais das equipes de Saúde da Família do Distrito Federal. Saúde Soc [Internet]. 2013 [cited 2016 Jun 08];22(1):109-23. Available from: http://www.scielo.br/pdf/sausoc/v22n1/11.pdf

24. Longpré C, Dubois CA, Nguemeleu ET. Associations between level of services integration and nurses' workplace well-being. BMC Nurs [Internet]. 2014 [cited 2016 Oct 02];13:50. Available from: https://bmcnurs.biomedcentral.com/articles/10.1186/ s12912-014-0050-X

25. Fracolli LA, Zoboli ELP, Granja GF, Ermel RC. The concept and practice of comprehensiveness in Primary Health Care: nurses' perception. Rev Esc Enferm USP [Internet]. 2011 [cited 2016 Jun 08];45(5):1132-8. Available from: http://www.scielo.br/pdf/ reeusp/v45n5/en_v45n5a15.pdf

26. Bernardino E, Segui MLH, Lemos MB, Peres AM. Enfermeira de ligação: uma estratégia de integração em rede. Rev Bras Enferm [Internet]. 2010 [cited 2016 Jun 08];63(3):459-63. Available from: http://www.scielo.br/pdf/reben/v63n3/a18v63n3.pdf 